\title{
Characterization, classification and suitability ratings of soils for rainfed rice production in Rukubi, Doma, Nasarawa State, Nigeria
}

\author{
Kyat M. M and S. Idoga \\ Department of Soil Science, University of Agriculture, Makurdi, Nigeria. \\ Corresponding Author: Email: kyatmark@yahoo.com
}

\begin{abstract}
Rice is an important annual crop in Nigeria. It is one of the major staples, which can provide a nation's population with the nationally required food. The objectives of this study were to characterize, classify and determine the suitability ratings of some soils of Rukubi for rainfed rice production. All the soil units were deep $(150-199 \mathrm{~cm})$, unit III soils were well drained, while units I and II soils were somewhat poorly drained. The soils had textures ranging between sandy clay loam and clay loam. The soils were well structured (strong coarse sub-angular blocky). Soil reactions were slightly acid ( $p \mathrm{H} 5.12$ - 7.15 in $\mathrm{H}_{2} \mathrm{O}$ ). The organic carbon content of the soils were moderately low to high $(1.03-1.62 \%)$ in the surfaces, while low in the sub-surface horizons $(0.50-1.60 \%)$. The total nitrogen was low at the surface horizons and ranged between 0.01 and $0.16 \%$. The soils were dominated by $\mathrm{Ca}$ and $\mathrm{Mg}$ with values varying from $1.10-4.021 \mathrm{cmol} / \mathrm{kg}$ and $0.05-3.89$ cmol/kg respectively. The available phosphorus was relatively high in the surfaces $(4.10-11.8 \mathrm{mg} / \mathrm{kg})$, but, much lower in the sub-surfaces $(14.15-9.85 \mathrm{mg} / \mathrm{kg})$. The percentage base saturation of the soil ranged from $47 \%$ to $98 \%$. Based on the physical and chemical characteristics, the soils of unit I 1were classified as TypicEndoaquepts/ AndicFluvisols; unit II was classified as EutricEndoaquepts/ AndicCambisols and unit III as ArenicEndoaquepts/ EutricFluvisols. The characteristics of the soil units were compared with the land requirements for rice production. On suitability rating, all of the soil units highly suitable for rainfed rice production.

Keywords-Rainfed rice, suitability ratings, soils.
\end{abstract}

\section{INTRODUCTION}

Cereals are one of the important foods for growing population of human. Approximately $50 \%$ of consumed calories by the whole population of humans depend on wheat, Rice and maize (Gnanamanickam, 2009). Although rice has the second place because of planted area but it serves as the most important food source for Asian countries mainly in south-east parts where it is an economic crop for farmers and workers who grow it on millions of hectares throughout the region (Gomez 2001). Historically, rice was cultivated 10000 years ago in the river valleys of South and Southeast Asia and China since it served as the most important food for people. Although Asia is the main place of rice cultivation but it was harvested in other continents like Latin America, Europe, some parts of Africa and even USA (Gnanamanickam, 2009).

The rice sector in Nigeria is one of the most important remarkable agricultural developments over the decades. It is the most consumed staple food by Nigeria's over 174 million people across states and geo-political zones. There is lopsidedness in the level of production of rice in Nigeria as compared to its consumption pattern. The implication is that, to meet up with the high demand for its consumption, the rice has to be imported and these have been on the high side and it is inelastic.

In the light of this, Frederic et al. (2003) observed that, with rice now being the structural component of the Nigerian diet, and rice imports making up an important share of Nigeria's agricultural imports, there is considerable political interest in increasing the consumption of local rice. This has made rice a highly political commodity.

Akpokodjeet al. (2001) maintained that, a comprehensive and up to date picture of rice sector in Nigeria in general and rice production, processing and consumption in particular is lacking. It can be seemingly noticed that, despite its agricultural potentials, Nigeria is yet to harness its vastland resources suitable for agriculture, to not only improve its export on rice, but even to cater for its domestic consumption which will invariably serve for sufficient food security. This is evident from the fact that, rice consumption in Nigeria increases over decades and in alarming rates. 
Although, the total rice production is increasing recently due to high demands; the recorded increase however, have not been sufficient to meet the increasing demand from the rapidly growing population; estimated at over 174 million people.

Osagie (2014) observed that Nigeria currently spends about a billion Naira daily importing rice. The Nigerian government recently came up with a policy decision to ban rice importation completely by 2015 . The question is how prepared is the Nigerian government towards ensuring that, this policy intentions are actualized? Considering the fact that, the United States Department of Agriculture reveals that, Nigeria's rice imports in 2012 to 2013 alone were estimated to reach about 3 million tones. This is mainly because, the projected increase in rice production in 2012 to 2013 falls short of consumption requirements.

\section{MATERIALS AND METHODS}

The study area is Rukubi, located at about $81 \mathrm{~km}$ Southwest of Lafia and $40 \mathrm{~km}$ North-west of Makurdi town. The area lies between Latitudes $7^{0} 19^{1} 28^{11}$ and $7^{0} 55^{1} 45^{11} \mathrm{~N}$, Longitudes $8^{0} 30^{1} 56^{11}$ and $8^{0} 18^{1} 20^{11} \mathrm{E}$, and the altitude of $252 \mathrm{~m}$ above sea level (asl). The area experiences distinct wet and dry seasons with the mean annual rainfall of about $1307 \mathrm{~mm}$ falling between April and October of most years. The mean average temperature is about $27.4^{0} \mathrm{C}$. The monthly minimum temperature is between $16.2^{0} \mathrm{C}-17.2^{0} \mathrm{C}$.
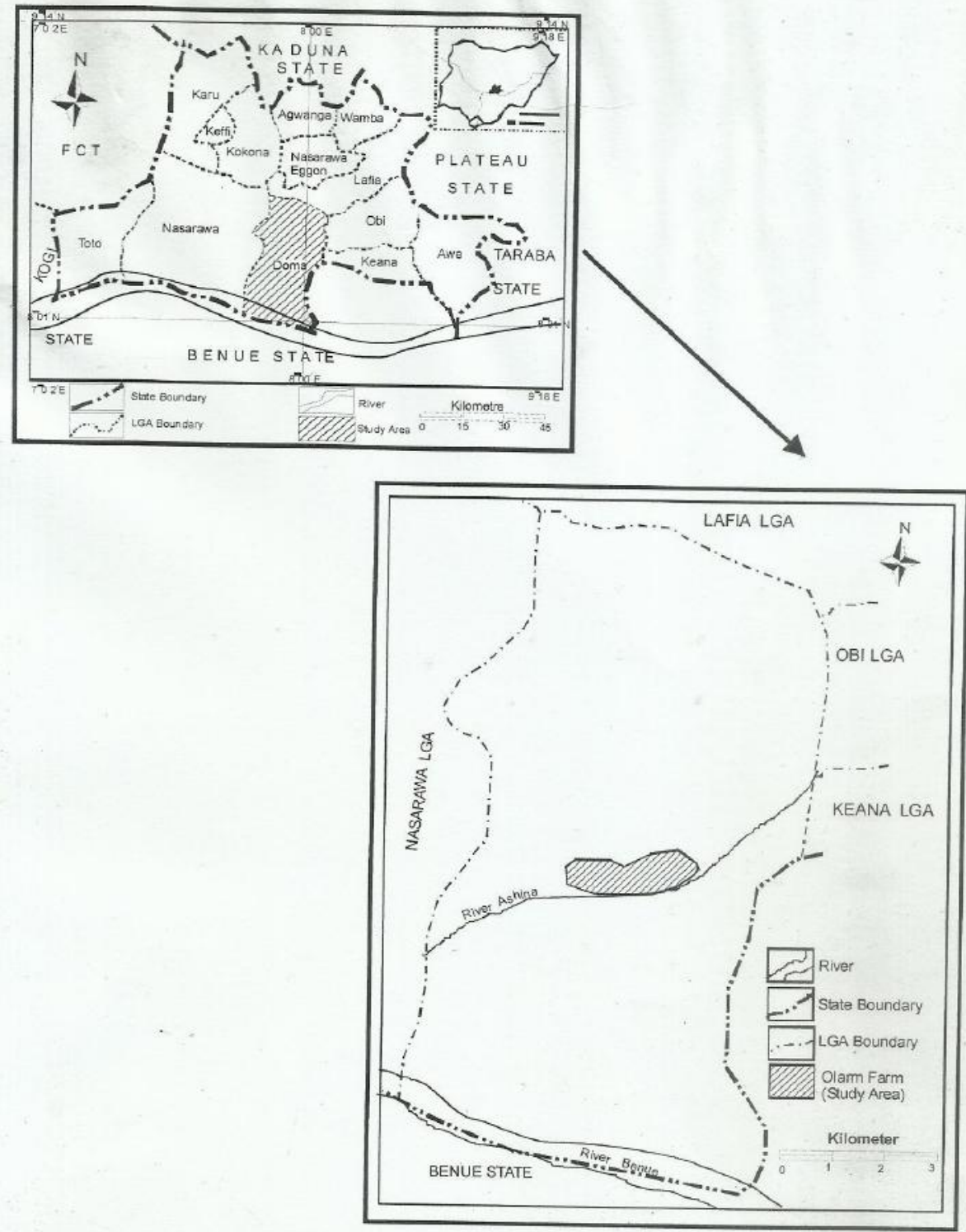

Fig.1: Map of Nasarawa State showing the study area 
The geomorphology of the area shows that the rock types are making up the components of Nigerian geology (Basement, Younger Granites and Sedimentary rocks). The basement complex cover up to $60 \%$ of the total area of the area, while the remaining $40 \%$ is made of sedimentary rocks of the middle Benue Trough.The area is composed of undulating lowlands and network topography with little or no rock outcrops (Nyagba, 1995).

\section{Field Studies}

About 300 ha of the extensive farmland at Olam were soilsurveyed using grid method with traverses cut at $200 \mathrm{~m}$ perpendicular to the baseline. Auger point investigations were conducted at $200 \mathrm{~m}$ interval. Different soil types were identified using morphological characteristics such as colour, texture, structures, topography, consistence, and surface characteristics as differentiating features for delineating soil boundaries. Two pits will sunk in each soil unit, described using the guidelines of soil profile descriptions (soil survey staff, 2014). Sampling were done for each identified horizon

The soil samples from each representative soil unit were collected into polythene bags, neatly labeled and taken to the laboratory for physical and chemical analysis. Based on the data obtained from the soil survey, the soils at Rukubi were subsequently characterized, clas sified and mapped.

The soil samples were air-dried, gently crushed and sieved to obtain the fine earth fraction $(<2 \mathrm{~mm})$. Soil bulk density were determined by the undisturbed core sampling method after drying the soil samples in an oven at $105{ }^{0} \mathrm{C}$ to constant weights, while particle density were measured by the pycnometer method (Black, 1965). Percentage pore space was computed from the values of bulk density and particle density (Brady and Weil, 2002) as total pore space $($ percentage $)=(1-\mathrm{BD} / \mathrm{PD}) \times 100$.

The laboratory analysis was carried out included particle size distribution using hydrometer method as described by Day (1965). Soil pH was determined by electrometer method as described by Hesse (1971). Soil organic carbon was determined by Walkey Black method based on the oxidation of organic matter by potassium dichromate (Hesse, 1971). Total nitrogen was determined using macro Kjeldahl procedures. Available phosphorus determined using Bray 1 method (IITA, 1979). The exchangeable bases were extracted using neutral $\mathrm{NH}_{4} \mathrm{OAC}$ as displacing solution. Calcium and Magnesium were read on atomic absorption spectrophotometer, while Potassium and sodium were read on flame photometer. Exchange acidity was determined using Barium Chloride Triethanolamine as described by Peech (1965). Effective cation exchange capacity was calculated as the sum of exchange acidity and exchangeable bases. The percentage base saturation was calculated as total exchangeable bases divided by effective cation exchange capacity multiplied by 100 .

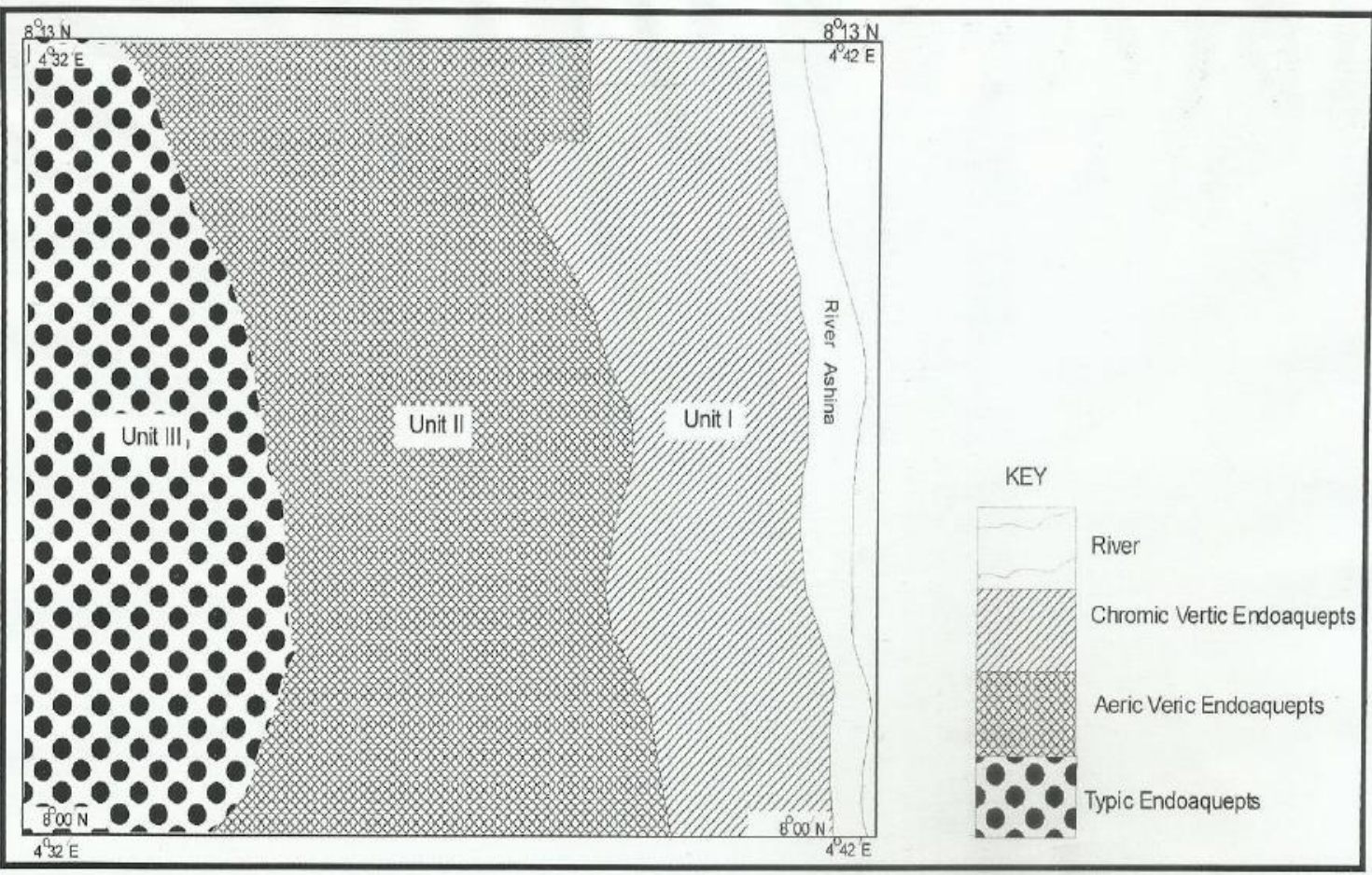

Fig.2: Soil Map of Rukubi 


\section{RESULTS AND DISCUSSIONS}

\section{Soil morphological characteristics}

Figure 1 shows distribution of the three mapping units. The soils were generally poorly drained. They were fine textured with clay content ranging from $10.7 \%$ and $40.0 \%$, this could be as result of the shale parent material. The clay and sand content distribution was irregular across the horizons except for sand in unit III were the sand content decreased with increase in depth. This could be as result of intense disturbances caused heavy machinery used in farming by Olam rice farm. More so, the irregular pattern in most of the units could be due to different types of sediment with varying textures deposited annually in accordance to their source. The structure of the surface horizon in all the soil units was strong coarse sub- angular blocky possibly as a result of high organic and clay contents.

\section{Soil chemical properties}

The $\mathrm{pH}$ value of the soils of the study area as shown in Table 1 indicates that the soils were slightly acid in reaction. Soil $\mathrm{pH}$ of surface horizon ranged 5.12 and 7.1. These figures mostly decreased with depth probably due to the effect of nutrient biocycling (Ogunwale et al., 2002) the percentage organic carbon was highest $1.62 \%$ in pedon 3 probably due to incorporation of the crop residues to the soil. The total nitrogen values of the soils ranged between 0.01 to $0.70 \%$. These nitrogen levels are very low for surface horizons of soils as rated by (IRRI, 1995) and probably due to release from plant tissues, gaseous loss and volatilization (De Datta, et al., 1991).

The available phosphorus values were relatively high (11.8 $\mathrm{cmol} / \mathrm{kg}$ ). The values decrease with increasing depth. This is perhaps due to the relationship of organic carbon with phosphorus (Miura et al., 1997).

Exchangeable $\mathrm{Ca}$ and $\mathrm{Mg}$ dominated over $\mathrm{K}$ and $\mathrm{Na}$ in the exchange complex. This is in agreement with earlier finding of Fagbami and Akamigbo, (1986). The values of exchange acidity were generally low and ranged between 0.88 to 1.80 $\mathrm{cmol} / \mathrm{kg}$. Effective cation exchange capacity values were low and ranged between $3.39 \mathrm{cmol} / \mathrm{kg}$ and $9.70 \mathrm{cmol} / \mathrm{kg}$ of soil, which is rated as low to moderate (FAO, 1983). This may probably be due to the contribution of clay (Idoga and Azagaku, 2005). The percentage base saturation was rated from moderate to high, ranging from $47 \%$ to $98 \%$. This could be linked to the active plant litter decomposition process, which incorporates cations from the litter into the soil surface (Malgwi, 1979).

The USDA soil taxonomy (soil survey staff, 2014) and the WRB, (2006) were used in classifying the soils of the area. Both field and laboratory studies of the soils of the area indicate an increasing trend in the amount of clay with depth (especially unit III) and also high degree of aggregation. The clay distribution pattern shows that there is argillic horizon in all the profiles studied. This clay distribution pattern corresponds with the high base saturation status of the soils therefore qualifying them as Alfisols. The presence of mottles mostly near the soil surface, a chroma of 2 in some horizons qualifies the soils as Aqualfs. Soil units II and III show evidence of episaturation by the presence of mottles at or near the soil surface and the dominant hue of $10 \mathrm{YR}$ and $2.5 \mathrm{Y}$; they therefore qualify as Epiaqualfs. They further qualify as AericVerticEndoaqualfs and ChromicVerticEndoaqualfs because of the presence of cracks narrower than $2 \mathrm{~cm}$ and shallower than $50 \mathrm{~cm}$, as well as the dominance of hue of 7.5YR, and 10YR. All the soil units showed irregular but decreasing clay content with depth. They therefore classified as Inceptisols. This inferred ustic soil moisture regime of the area places these soils into the suborder ustept. The clay distribution pattern of the soils places them in the great group Haplustepts. They further classified as AquicHaplustepts because of aquic soil moisture regime within $70 \mathrm{~cm}$ of soil surface.

In the WRB (2006), the soils have high clay content in the subsoilthan in the topsoilas a result of pedogenic processes (elluviation and Illuviation) leading to an Argic subsoil horizon. All soil units have evidence of redoximorphic features caused by subsurface water, which periodically wet both the topsoil and the subsoil over a considerably period of time leading to the formation of mottles. For these reasons, they are classified as Luvisols (WRB, 2006). They further qualify as VerticLuvisols because of vertic properties within $100 \mathrm{~cm}$ of soil surface and higher clay content of the subsoil as well as the high base status of the soils. 


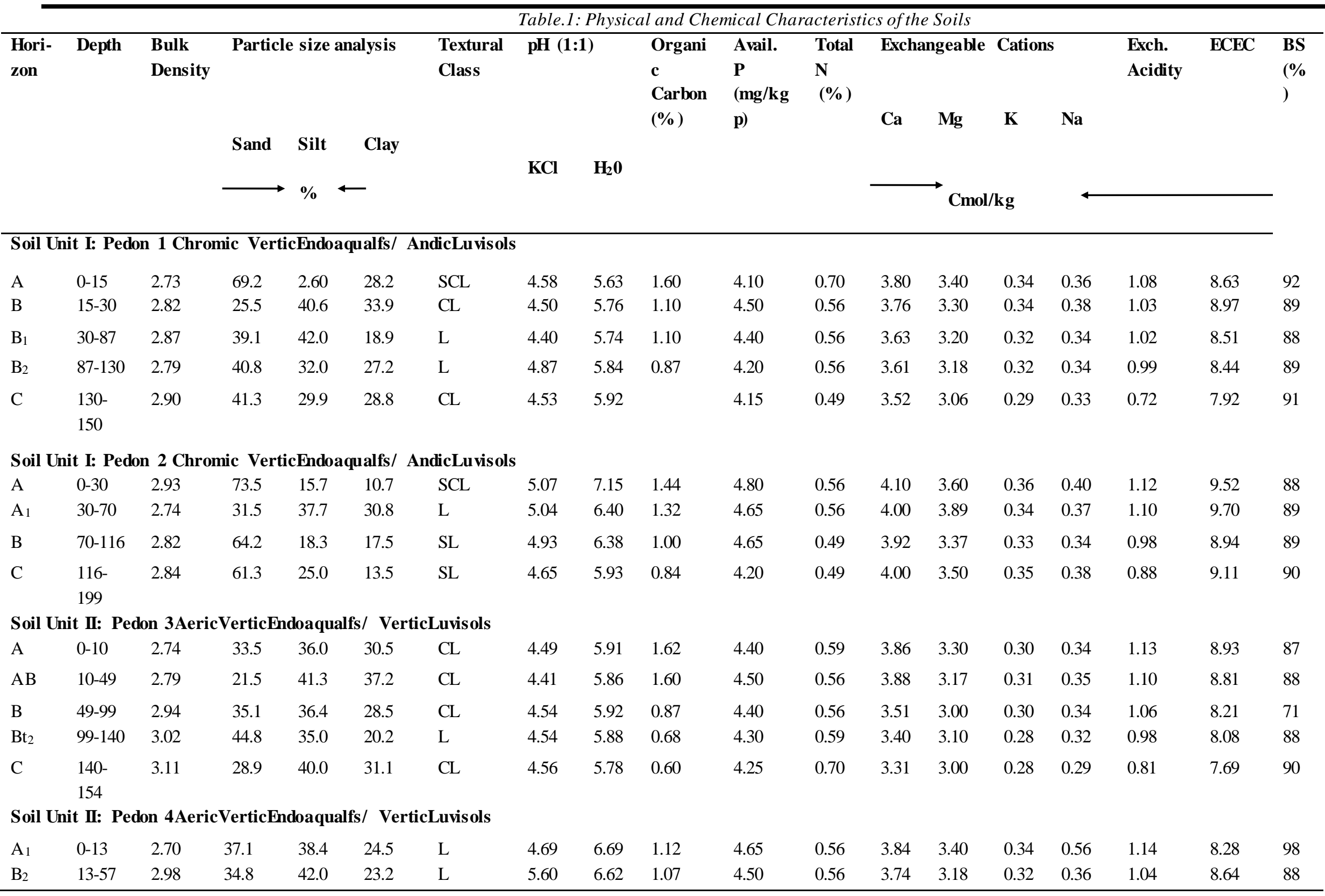




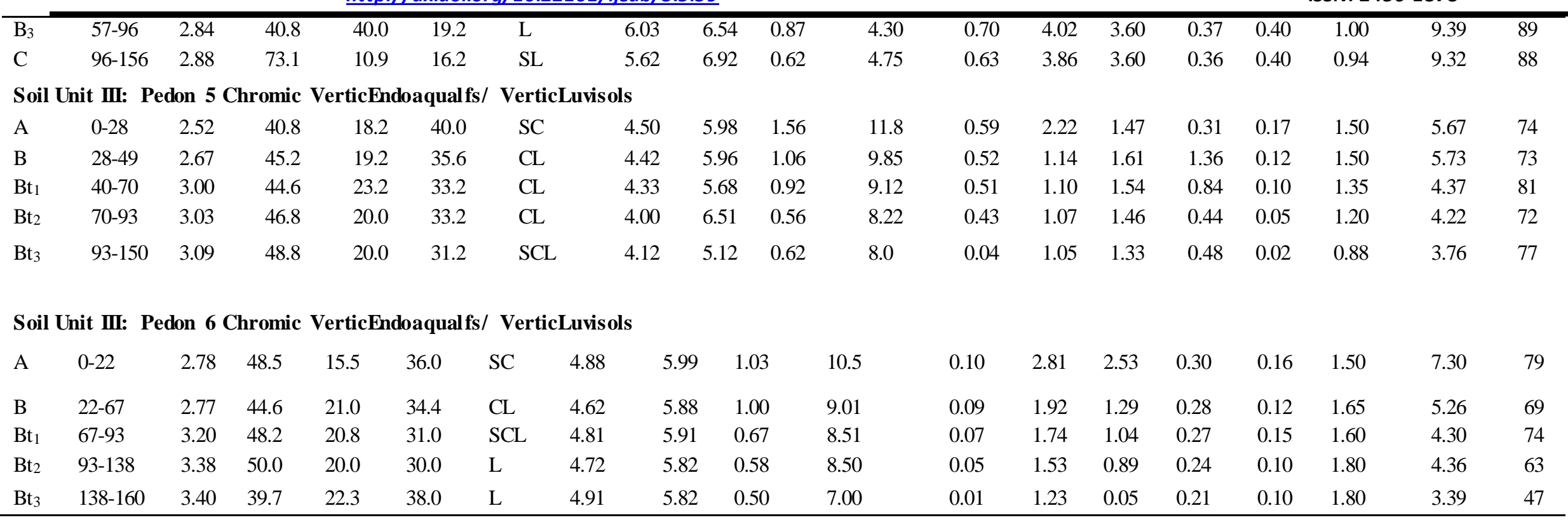

Source :Field Studies

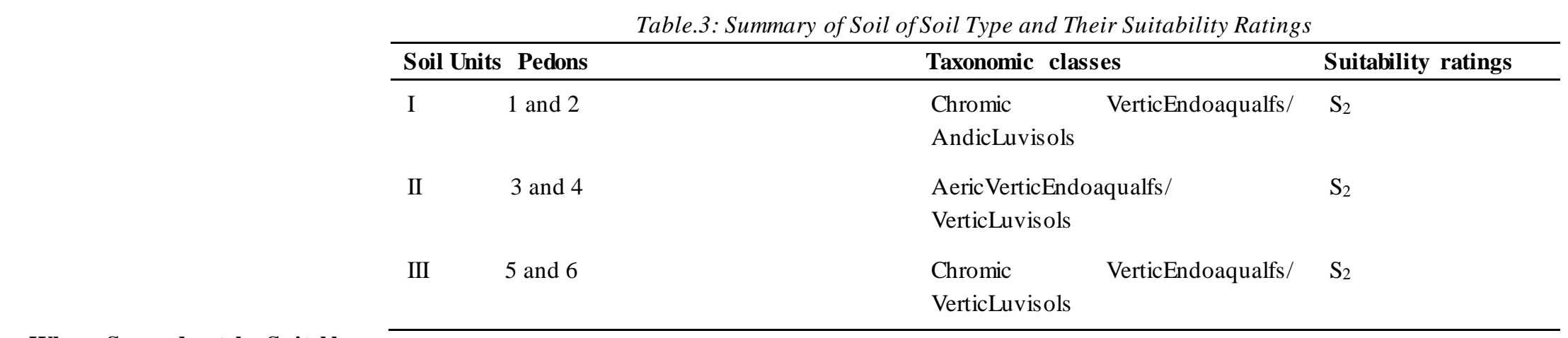




\section{Suitability ratings for rainfed rice production}

Suitability ratings derived from the results of soil survey work (Fagbemi and Akamigbo, 1986). The interpretation of soil survey work itself is a statement of prediction of performance. Suitability ratings is therefore, carried out by comparing the characteristics of the soils with the requirements of the crop in this case, rice. The chemical characteristics of the soils such as $\mathrm{pH}$, organic matter, exchangeable bases, effective cation exchange capacity, and exchange acidity are found to be conducive to rice production or can be mended by individual farmers and therefore cannot be permanent limitations.

All mapping units were very deep $(>120 \mathrm{~cm})$ and all are considered suitable for the production of rice. However, all the pedons have characteristic mottling at the subsurface through to the last horizon. This probably accounted for the observed redoximorphic condition in all the soil units indicated by the presence of few fine medium to coarse and distinct to prominent mottles occurring within the horizons. However, the soil may not have been under permanent water saturation for a period longer than few weeks as indicated by soil colour which ranged from the texture of the soils ranged from clay loam to sandy clay loam. According to Sys $(1991,1993)$, rice require loamy clay to sandy loam clay for optimum yield. Thus, the soils in pedon unit I and III present a very slight limitation to rice yield, while soil unit II seems to possess no textural limitation to rice production, hence, it is highly suitable. The structure of the soils ranged between fine sub angular blocky to coarse sub angular blocky. Coarse sub angular blocky is regarded as highly suitable for rice production (Sys, 1991). The structures of all the mapping units were considered highly suitable for rice production. The soil chemical properties, which could affect their suitability for rainfed, rice production are acidity, salinity, and fertility. The reactions of the soils ranged from slightly acidic to neutral ( $\mathrm{pH} 5.12$ to 7.15). Although this $\mathrm{pH}$ level may not pose serious problem for $\mathrm{P}$ uptake, $\mathrm{pH}$ above 6.0 may limit the availability of micronutrients such as $\mathrm{Fe}, \mathrm{Zn}, \mathrm{Mn}$ and $\mathrm{Cu}$ which form metallic cations that precipitate into low solubility compounds at high $\mathrm{pH}$ levels. Total exchangeable acidity $\left(\mathrm{H}^{+}+\mathrm{Al}^{+}\right)$ranged between $0.72 \mathrm{cmol} / \mathrm{kg}$ and 1.80 $\mathrm{cmol} / \mathrm{kg}$ indicating that the level of exchangeable aluminium was below toxic range (Tanaka and Yoshida 1970). The soils have low to medium levels of exchangeable $\mathrm{Ca}, \mathrm{Mg}, \mathrm{K}, \mathrm{Na}$ and of $\mathrm{N}$ and medium to high levels of Bray-1 P. All with the exception $\mathrm{P}$, the major nutrient content in the soil were lower than the critical requirement for rice production (De Datta, 1989). The result of the survey revealed that the levels of organic matter, nitrogen, exchangeable cations and $\mathrm{Mn}$ were below the critical requirements for rice production (Adeoye, 2002).

Appendix A: Land Requirement for Suitability Classes For rain-fed Rice Production

\begin{tabular}{|c|c|c|c|c|c|c|}
\hline Land Qualities & $\mathbf{S 1}$ & $\mathbf{S 2}$ & & S3 & $\mathbf{N}$ & \\
\hline \multicolumn{7}{|l|}{ CLIMATE } \\
\hline Annual Rainfall & $>1000$ & $900-1000$ & $800-900$ & $600-800$ & $600-500$ & $<500$ \\
\hline Mean annual temperature $\left({ }^{\circ} \mathrm{C}\right)$ & $>25$ & $22-25$ & $20-22$ & $18-20$ & $16-18$ & $<16$ \\
\hline Relative Humidity (\%) & $>75$ & $70-75$ & $65-70$ & $60-65$ & $<60$ & \\
\hline Topography: Slope (\%) & $<2$ & $3-4$ & $5-6$ & $7-8$ & $9-10$ & $>10$ \\
\hline \multicolumn{7}{|l|}{ DRAINAGE (s): } \\
\hline Wetness & $\mathrm{WD}(\mathrm{ID}) \dagger$ & MWD (ID) $\dagger$ & MD & $\mathrm{ID}(\mathrm{WD}) \dagger$ & $\mathrm{PD}(\mathrm{WD}) \dagger$ & $\begin{array}{l}\mathrm{PD} \\
(\mathrm{WD}) \dagger\end{array}$ \\
\hline Flooding & Fo & Fo & $\mathrm{F} 1$ & $\mathrm{~F} 1$ & $\mathrm{~F} 2$ & F3 \\
\hline $\begin{array}{ll}\text { SOIL } & \text { PHYSICAL } \\
\text { PROPERTIES } & \end{array}$ & \multicolumn{5}{|c|}{ PROPERTIES } & \\
\hline Texture & $\mathrm{L}(\mathrm{LC}) \dagger$ & Lfs (SLC) $\dagger$ & $\mathrm{LS}(\mathrm{SL}) \dagger$ & $\mathrm{S}$ & $\mathrm{S}$ & $\mathrm{S}$ \\
\hline Structure & $\mathrm{Cr}(\mathrm{SAB}) \dagger$ & $\mathrm{C}(\mathrm{SAB}) \dagger$ & $\mathrm{SAB}(\mathrm{Cr}) \dagger$ & $\mathrm{SAB}(\mathrm{Cr}) \dagger$ & $\mathrm{Col}(\mathrm{Cr}) \dagger$ & $\begin{array}{l}\text { Col }(\mathrm{Cr}) \\
\dagger\end{array}$ \\
\hline Coarse fragment $(\%)(0-45 \mathrm{~cm})$ & $<3$ & $3-5$ & $5-10$ & $10-15$ & $>15$ & \\
\hline Soil Depth (cm) & $>75$ & $65-70$ & $50-65$ & $35-50$ & $30-35$ & $<30$ \\
\hline \multicolumn{7}{|l|}{ FERTILITY (F) } \\
\hline $\mathrm{pH}$ & $5.5-6.5$ & $5.0-5.5$ & $4.5-5.0$ & 4.0 & 4.5 & $<4.0$ \\
\hline Base Saturation & $>80$ & $70-80$ & $50-70$ & $40-50$ & $25-35$ & $<25$ \\
\hline
\end{tabular}




\begin{tabular}{|c|c|c|c|c|c|c|}
\hline Organic Carbon $(\%)(0-30 \mathrm{~cm})$ & $>2.0$ & $2.0-1.5$ & $1.2-1.5$ & $1.0-1.2$ & 1.0 & $<1.0$ \\
\hline \multicolumn{7}{|l|}{ MACRO-NUTRIENTS } \\
\hline Nitrogen $(\%)$ & $>2.0$ & $1.5-2.0$ & $1.0-1.5$ & $0.5-1.0$ & $<0.5$ & \multirow{3}{*}{$<3$} \\
\hline Phosphorus (mg kg-1) & $>20$ & $15-20$ & $8-15$ & $5-8$ & $3-5$ & \\
\hline Potassium (cmol kg-1) & $>0.5$ & $0.3-0.5$ & $0.2-0.3$ & $0.1-0.2$ & $<0.1$ & \\
\hline \multicolumn{7}{|l|}{ MICRO-NUTRIENTS } \\
\hline Iron $(\mathrm{Fe})\left(\mathrm{mg} \mathrm{kg}^{-1}\right)$ & $>4.5$ & $3.5-4.5$ & $2.5-3.5$ & $1.5-2.5$ & $1.0-1.5$ & $<1.0$ \\
\hline Zinc $(\mathrm{Zn})\left(\mathrm{mg} \mathrm{kg}^{-1}\right)$ & $2.0-2.5$ & $1.5-2.0$ & $1.0-1.5$ & $0.8-1.0$ & $0.6-0.8$ & $<0.6$ \\
\hline Manganese $(\mathrm{Mn})\left(\mathrm{mg} \mathrm{kg}^{-1}\right)$ & $1.5-1.7$ & $1.0-1.5$ & $0.8-1.0$ & $0.6-0.8$ & $0.5-0.6$ & $<0.5$ \\
\hline
\end{tabular}

\section{Source: Sys et al., (1991, 1993); De Datta (1989)}

$\dagger=$ ratings for lowland rice production; $\mathrm{SAB}=\mathrm{Sub}-\mathrm{Angular}$ Blocky; Col= Columnar; $\mathrm{Cr}=\mathrm{Crumb}$; WD= Well Drained; $\mathrm{MWD}=$ Moderately Well Drained; ID= Imperfectly Drained; $\mathrm{PD}=$ Poorly Drained; L= Loamy; SL= Sandy Loam; LS= Loamy Sand; Lfs= Loamy fine sand; SCL= Sandy Clay Loam; Fo= Rarely flooded; F1= Flooding expected; F2= Irregularly Flooded; F3= Regularly Flooded

The climate of the studied area is quite favourable for the production of rice. The mean annual temperature $\left(27^{\circ} \mathrm{C}\right.$ $30^{\circ} \mathrm{C}$ ), average sunshine hours ( $>5$ hours), total annual rainfall and distribution pattern $(>1000)$ and relative humidity during cropping season $(>75 \%)$ are all adequate by the standard of Sys (1993). The topography of the toposequence is also considered adequate (Slope between $<1-2 \%)$.

\section{REFERENCES}

[1] Akpokodje, E. G. (2001).Introduction to Engineering Geology properties of Earth Materials, Engineering Geology, Port Harcourt pp 1. 147

[2] Black, C. A. (1965). Methods of soil analysis. Part I, American Society of Agronomy. Madison, Wisconsin, USA. $1572 \mathrm{p}$.

[3] Brady, N. C. and Weil, R. R. (2002). The nature and properties of soils, $13^{\text {th }}$ Ed. Prentice- Hall Inc., New Jersey, USA. 960p.

[4] Day, P. R. (1965). Particle fractionation and particle-size analysis. Chap. 43 in Methods of Soil Analysis, Part 1. C.A. Black, ed. American Society of Agronomy, Madison. Pp. 545-567.

[5] De Datta, S. K., Samson, M. I., Buresh, R. J (1991). Quantification of denitrification in flooded soils as affected by rice establishment method.Soil Biology and Biochemistry Volume 25, Issue 7, July 1993, Pages 843-848

[6] Fagbami,A.,Akamigbo, F. O. R. (1986).The soils of Benue State and their capabilities.14th Annual conference of soil science society of Nigeria.Makurdi.pp 6-23

[7] Food and Agricultural organization of the United Nations FAO (1983).World referencebase for soil resource.Food and Agricultural organization of the United Nations. Rome
[8] Frederic, V. (2003).The Process of Soil Excavation in a Community.Site-Specific Determinants of Stress Perception.First

[9] 5Published September 1, 2006 Research Article

[10] Gnanamanickam, S. S. (2009). Rice and Its Importance to Human Life.ProgBiol Con 8: 1- 11. 2.

[11] Gomez, J. A., Nearing, M. A., Giraldez, J. V., Albert, E. E. (2001) Analysis of sources of variability of runoff volume in a 40 plot experiment using a numerical model

[12] Idoga, S., Azagaku, D. E. (2005).Characterization and Classification of soils of Janta Area, Plateau State of Nigeria.Nigeria Journal of Soil Science. 15:116-122

[13] International Institute of Tropical Agriculture IITA (1979).Selected methods for soil and plant analysis.Manual series No. 1. Ibadan, Nigeria: IITA, 3-12.Journal of Hydrology, 248 (1-4) (2001), pp. 183-197

[14] Malgwi, W. B., Ojanuga, A. G., Chude, V. O. T., Kparmwang, B., Raji, B. A. (1986). Morphological and physical properties of some soils at Samaru, Zaria, Nigeira. Nigeria Journal of Soil Research, Department of soil science Ahmadu Bello University, Zaria, Nigeria pp. $58-64$

[15] Miura, T., Kawamura, S., Miura, C., Yamauchi, K. (1997). Impaired spermatogenesis in the Japanese eel, Anguilla japonica: Possibility for the existence of factors that regulate entry of germ cells into meiosis. Dev Growth Differ 39: 685-691

[16] Moody, K., and Fiedler, L. (1985). Illustrated Guide to Integrated Pest Management in Rice in Tropical Asia. Inter Rice Res Inst Philippines.

[17] Nyagba, J. L. (1995). The Geography of Benue State. In DJ Denga (Ed.) "Benue State: The Land of 
Great Potentials" A Compendium. Calabar, Nigeria: Rapid Educational Publisher Limited.

[18] Ogunwale, J. A., Olaniyan, J. O., Aduloju, M. O. (2002).Morphological, Physico-Chemical and Clay Mineralogical Properties of Soil Overlying Basement Complex Rocks in Ilorin East, Nigeria. Moor Journal of Agricultural Research. 3 (21):147164

[19] Osagie, E. I. (2004). Adsorption of Naphthalene on Clay and Sandy Soil from Aqueous Solution. Advances in Chemical Engineering and Science 5: 345.

[20] Peech, M. (1965).Hydrogen-ion activity in Methods of Soil Analysis Part 2; C.A. Black, ed. pp. 914-926.

[21] Sys, C., van Ranst, E., and Debaveye, J. (1991). Land Evaluation Part I: Principles in Land Evaluation and Crop Production Calculations. Agricultural Publications No. 7, General Administration for Development Cooperation, Brussels, Belgium, Pages: 274.

[22] Sys, C., van Ranst, E., Dehaveye, J., and Beernaert, F. (1993). Land Evaluation Part III: Crop Requirements. Agricultural Publications No. 7, General Administration for Development Cooperation, Brussels, Belgium, Pages: 199.

[23] Tanaka, A., and S. Yoshida, (1970). Nutritional dis orders of the rice plant in Asia. Proceedings of the International Rice Research Institute, November 1970, Los Banos, Philippines, pp: 51

[24] World reference base for soil resources WRB (2006).A framework for international classification, correlation and communication. 